\title{
Sofosbuvir-Upregulated Genes Facilitate The Development of Hepatocellular Carcinoma
}

\author{
Wei-Lun Tsai ( $\nabla$ tsaiwl@yahoo.com.tw ) \\ Kaohsiung Veterans General Hospital https://orcid.org/0000-0001-7557-3370 \\ Jing-Shiung Cheng \\ Kaohsiung Veterans General Hospital \\ Pei-Feng Liu \\ Kaohsiung Medical University \\ Tsung-Hsien Chang \\ National Defense Medical Center \\ Yu-yi Chang \\ Kaohsiung Veterans General Hospital \\ Wei-Chih Sun \\ Kaohsiung Veterans General Hospital \\ Wen-Chi Chen \\ Kaohsiung Veterans General Hospital \\ Chih-Wen Shu \\ national sun yat-sen university
}

\section{Research}

Keywords: Hepatitis C, hepatocellular carcinoma, sofosbuvir

Posted Date: December 22nd, 2020

DOl: https://doi.org/10.21203/rs.3.rs-130882/v1

License: (1) (1) This work is licensed under a Creative Commons Attribution 4.0 International License.

Read Full License 


\section{Abstract}

Background: Direct-acting antivirals (DAAs) have achieved a sustained virological response (SVR) rate of 95-99\% in treating HCV. Several studies suggested that treatment with sofosbuvir (SOF) containing DAAs may be associated with increased risk of developing HCC. The aim of this study is to investigate the potential mechanisms of SOF on the development of HCC.

Methods: This study used OR-6 (harboring full-length genotype 1b HCV) and Huh 7.5.1 cells to examine the effects of SOF on cell proliferation and migration in HCC cells. SOF-upregulated genes in OR- 6 cells were inspected using next generation sequencing (NGS) and the clinical significance of these candidate genes was analyzed using The Cancer Genome Atlas (TCGA) database. siRNA-mediated knockdown of candidate genes and their influence on cell proliferation and migration were also examined.

Results: SOF increased cell proliferation and cell migration in OR-6 and Huh7.5.1 cells in both two- and three-dimensional culture models. NGS identified several genes that were significantly upregulated by SOF in OR-6 cells. Among these genes, PHOSPHO2, KLHL23, TRIM39, TSNAX-DISC1 and RPP21 expression were significantly elevated in the tumor part compared with the non-tumor part of HCC in the TCGA database. PHOSPHO2 and RPP21 were found to be associated with overall survival of HCC patients in the TCGA database. Moreover, knockdown of PHOSPHO2-KLHL23, TSNAX-DISC1, TRIM39 and RPP21 ameliorated cell proliferation and migration increased by SOF in OR-6 and Huh 7.5.1 cells.

Conclusion: SOF upregulated several genes that were associated with increased cell proliferation and migration and the development of HCC.

\section{Background}

Taiwan, the prevalence rate of hepatitis $\mathrm{C}$ virus $(\mathrm{HCV})$ infection is around $2-5 \%$ and $\mathrm{HCV}$ is a major cause of cirrhosis and hepatocellular carcinoma (HCC) worldwide[1]. In patients with acute HCV infection, 60$90 \%$ will become chronic infection and $20-30 \%$ will develop cirrhosis of liver or HCC after 20-30 years of chronic infection[2, 3]. In recent years, anti-HCV therapy has made a tremendous progress. Understanding the life cycle of HCV, along with the development of replicative cell culture systems, has led to the discovery of a number of potential targets for direct-acting antiviral (DAA) agents[4, 5]. Several oral regimens combining DAAs from different families including NS5B nucleotide inhibitors (NI), dNS5B nonnucleoside inhibitors (NNI), NS5A replication complex inhibitors and NS3/4A protease inhibitors (PI)] have been developed[6-9]. Sofosbuvir (SOF)-based regimen has been widely used for the treatment of chronic hepatitis $\mathrm{C}(\mathrm{CHC})$ and resulted in a sustained virological response (SVR) rate of $95-97 \%$ in compensated cirrhosis and $85-90 \%$ in patients with more advanced liver disease in most studies[2, 10-17].

However, some evidences showed that the DAA treatment did not eliminate the development of HCC in $\mathrm{CHC}$ patients[18-20]. A recent study by Reig et al. found that in $103 \mathrm{CHC}$ patients with history of HCC who received DAA treatment, 16 (27.6\%) developed tumor recurrence after a median follow-up of 5.7 months[21]. In another study, Conti et al. discovered that among 344 cirrhotic patients who received DAA, 
HCC was detected in 26 (7.6\%) patients. Among them, 17 of 59 patients (28.81\%) with previous HCC and 9 of 285 patients (3.16\%) without previous HCC developed HCC; and history of HCC was independently associated with HCC development[22]. From a Spanish real-world cohort, among the $70 \mathrm{CHC}$ patients with history of HCC, HCC recurred in 21 (30\%) within 12 months of starting DAA therapy[23]. However, there are also many studies that failed to show an increased HCC recurrence following HCV treatment with DAAs[24-26]. Nevertheless, most of these studies are retrospectively designed and no randomized controlled studies have ever been performed up to now owing to ethical concern. The issue remains controversial.

A recent study has found that DAA administration induces an early increase in serum VEGF and a change in the inflammatory pattern, coinciding with HCV clearance, but such changes reverse to normal after the end of treatment[27]. Another recent study also found that SOF activates an increase in EGFR expression and phosphorylation in hepatoma cells[28]. Another recent study has revealed association between levels of cytokines in serum and development of HCC in CHC patients treated with DAAs[29]. Another study also discovered that on-treatment decrease of NKG2D may be a useful predictor of early emerging HCC in patients treated with DAAs[30]. Hengst et al. also found that HCV infection appeared to disrupt the milieu of soluble inflammatory mediators even after viral clearance and HCV cure did not lead to complete immunological restitution[31]. Collectively, several recent studies have revealed that DAA treatment for $\mathrm{HCV}$ may induce changes in inflammatory microenvironment associated with the development of HCCs that can partly explain the increased occurrence of HCC in clinical settings. However, studies that aimed to identify the host risk factors associated with occurrence of HCC after DAA treatment are scarce. Perez et al. found that HCV-induced epigenetic changes reprogram host gene expression and persist following virus eradication[32]. These results may explain why some $\mathrm{CHC}$ patients proceed to the development of HCC after HCV eradication. However, there has been no research addressing the impact of SOFupregulated genes on the development of HCC in CHC patients. This study found that SOF increased cell proliferation and migration in HCC cells. Several SOF-upregulated genes identified by next-generation sequencing (NGS) were found to be associated with development of HCC according to The Cancer Genome Atlas (TCGA) database; and among them, several genes were associated with overall and disease-free survival. Knockdown of these genes reduced cell proliferation and migration increased by SOF in HCC cells.

\section{Material And Methods}

\section{Cell culture}

This study used Huh 7.5.1 cells and OR-6 cells. Huh 7.5.1 cells were provided by Dr. Francis Chisari and the OR- 6 cell line obtained from Dr Kato, ${ }^{33}$ harbored full-length genotype $1 \mathrm{~b}$ HCV RNA and coexpressed Renilla luciferase. Huh 7.5.1 cells were grown in Dulbecco's Modified Eagle's Medium (DMEM) supplemented with 10\% fetal bovine serum (FBS). OR-6 cells were grown in DMEM supplemented with 10\% FBS and $500 \mu \mathrm{g} / \mathrm{ml}$ of G418 (Promega, Madison, WI). 


\section{Real-time PCR}

After the identification of highly significant target genes, the primers for Q-PCR were designed using Primer Express 3.0 (Applied Biosystems, USA). Total cellular and viral RNA was isolated post-infection using RNeasy Mini columns (QIAGEN), reverse transcribed by random priming with the High Capacity cDNA Reverse Transcription Kit (Applied Biosystems; Foster City, CA), and then quantitated by real-time PCR using the DyNAmo HS SYBR Green qPCR Kit (Finnzyme; Espoo, Finland). The primers for the genes are as follows: PHOSPHO2-KLHL23 forward 5'- GGAATAGTTGGGATGTGTTGCTT-3' and reverse 5'GAGTGTGGAATAGATGGTCTCACAGA-3', TSNAX-DISC1 forward 5'-GGAAGATGCAGTTGAGAATGATGA-3' and reverse 5'-TCTTGTTCCAGGTCTTCTAATCTTTG-3', TRIM39 forward 5'- ACCACCACACCTTTTACCCC-3' and reverse 5'- TATGAGAGCGGTCTGTGACAT-3', RPP21 forward 5'- CTACACTGAGAGGACCATTGCG-3' and reverse 5'-TGTTAGGCAGGTCTGTACGGT-3', using GAPDH as normalization control.

\section{Cell viability assay}

Cell viability assay was performed as previously described. ${ }^{34}$ Briefly, hepatoma cells were seeded into 96well white plates overnight prior to treatment. The cells were lysed to determine cell viability with CellTiter Glo (Promega Corporation, G7571), which is a bioluminescent assay for measuring cellular ATP level, an indicator of metabolically active cells.

\section{Three-dimensional culture}

Three-dimensional cell culture was performed as previously described, with minor modifications. ${ }^{34}$ NanoCulture system was used for 3D cell culture (organogenix). First, $100 \mathrm{ul}$ of medium was added to each well. The plate was then centrifuged at $2000 \mathrm{~g}$ for $5 \mathrm{~min}$ to remove microbubbles, followed by incubation for 15-30 min at incubator. Each well was seeded with 50 ul of medium containing $5 \times 10^{3}$ cells. (If needed, transfection was conducted at this time point.) The plate was then kept on the bench at room temperature for 10-15 min until cells adhered to the bottom film. To avoid excessive evaporation of medium, phosphate buffered saline (PBS) was added to the gutter surrounding the plate. At $24 \mathrm{~h}, 50 \mu \mathrm{l}$ of medium (including drug) was added, and colony formation was observed after 4-6 days. Pictures of the colonies formed were taken and cell viability was measured with 3D CellTiter Glo (Promega Corporation)

\section{Migration assay}

In vitro wound assays were performed using IBIDI Culture-Inserts ( $35 \mathrm{~mm}$ with high culture-insert coating). First, $1.5 \times 10^{5}$ transfected cells in $140 \mu$ DMEM were seeded in the culture insert for $16 \mathrm{~h}$. The confluent monolayers of cells were washed twice with PBS to remove residual cell debris. Subsequently, culture inserts were removed and wound healing as indication of cancer migration took 6-9 h. Migration distance was measured in triplicate.

\section{Library preparation for transcriptome sequencing}


A total amount of $1 \mu \mathrm{g}$ RNA per sample was used as input material for the RNA sample preparations. Sequencing libraries were generated using TruSeq stranded mRNAlibrary prep Kit(cat\# RS-122-2101, Illumina, SanDiego, CA,USA)following manufacturer's recommendations and index codes were added to attribute sequences to each sample. Briefly, mRNA was purified from total RNAusing poly-T oligoattached magnetic beads and fragmented by heating. The first strand cDNA was synthesized using SuperScript II Reverse Transcriptase. PCR amplification was performed using 2X PCR Master Mix. After adenylation of 3 ' ends of DNA fragments, adaptors were ligated and the library fragments were purified with AMPure XP system (Beckman Coulter, Beverly, USA). The final library quality was assessed on the Agilent Bioanalyzer 2100 system using DNA High Sensitivity Chips. The libraries were sequenced on an Illumina NextSeq 500 platform and 75bp paired-end reads were generated.

\section{Bioinformatics Analysis}

The bioinformatics analysis pipeline is followed from sequencing step. Low quality bases and sequencing adapters in raw data which generated from Illumina sequencer was removed using program Trimmomatic, then the reads were aligned to reference transcript sequences using Bowtie2. Then, gene expression level was calculated by RSEM with Maximum likelihood abundance estimates using the Expectation Maximization (EM) algorithm for its statistical model. Differentially expressed genes (DEGs) are calculated by EBSeq, and the functional analysis, include GO and KEGG analysis, were using clusterProfiler.

\section{Establishment of gene knockdown cells (siRNA and transfection)}

Chemically synthesized siRNA oligonucleotides targeting candidate genes were purchased from QiagenXeragon (Germantown, MD) and designed using an siRNA design algorithm applying stringent homology analysis (https://www1.qiagen.com/Products/GeneSilencing/)CustomSiRna/CustomSiRna Order.aspx). Indicated siRNAs were transfected into cells using Lipofectamine ${ }^{\mathrm{TM}}$ RNAiMAX Transfection Reagent (Invitrogen, Carlsbad, CA). The negative control siRNA was obtained from QIAGEN. All siRNAs used for gene knockdown were SMART pools. Gene knockdown was confirmed by Q-PCR.

\section{Statistical Analysis}

Data were reported as mean \pm standard error of the mean (SEM) from three independent experiments. Results of cell proliferation assay and migration assay were analyzed using non-parametric two-tailed Student's t-test. Gene expression in the HCC patient dataset obtained from TCGA database (https://cancergenome.nih.gov/) was analyzed using analysis of variance (ANOVA) with Tukey's post-hoc test. Different levels of candidate genes between the tumor and corresponding non-tumor part were evaluated using the Wilcoxon signed-rank test. The cutoff for each gene expression level was determined according to receiver operating characteristic (ROC) curve and was divided into high and low groups. Cumulative survival curves were estimated using the Kaplan-Meier method. Univariate and multivariate Cox proportional hazards models for overall and disease-free survival were used for crude and adjusted hazard ratios, respectively. A $p$ value less than 0.05 (2-sided) was considered statistically significant. 


\section{Results}

\section{Sofosbuvir (SOF) increased cell proliferation and migration in hepatoma cells}

SOF-based regimen has been found to be associated with the development or recurrence of HCC especially in $\mathrm{CHC}$ patients with history of $\mathrm{HCC} .{ }^{21-23}$ Enhanced cell proliferation is a common feature for the development of HCC. Huh 7.5.1 cells and OR- 6 cells were used in the experiments. The OR- 6 cells harbored full-length genotype $1 \mathrm{~b}$ HCV RNA. The influence of SOF on cell proliferation was examined in this study. In OR-6 and Huh 7.5.1 cells treated with different doses of SOF ( 0.25 to $5 \mu \mathrm{M})$ for $24 \mathrm{~h}$, SOF increased cell proliferation in OR-6 and Huh7.5.1 cells in both two- and three-dimensional culture models (Fig. $1 \mathrm{~A}$ and $1 \mathrm{~B}$, respectively). Interferon- $\mathrm{a}$ and ribavirin combination therapy are recommended as the standard of care for $\mathrm{CHC}$ patients before the era of DAA. However, most previous studies on $\mathrm{CHC}$ patients who received interferon- $a$ with or without ribavirin treatment did not reveal an increased risk of HCC development. ${ }^{35-38}$ Interferon-a and ribavirin served as controls in this study. In OR-6 and Huh 7.5.1 cells treated with different doses of interferon- $\mathrm{a}(1$ to $1000 \mathrm{IU})$ and ribavirin $(0.1$ to $100 \mu \mathrm{M})$ for $24 \mathrm{~h}$, two- and three-dimensional cell proliferation were not significantly influenced (Fig. 1A and 1B, respectively).

Moreover, cancer cell migration is the typical feature involved in cancer metastasis. The effects of SOF on cell migration were examined in this study. In OR-6 and Huh 7.5.1 cells treated with different doses of SOF $(0.10$ to $2.5 \mu \mathrm{M})$ for $24 \mathrm{~h}$, cell migration was increased (Fig. 2A and 2B, respectively) in HCC cells exposed to SOF. Interferon- $a$ and ribavirin served as controls in this study. In OR-6 and Huh 7.5.1 cells treated with different doses of interferon- $\mathrm{a}(1$ to $1000 \mathrm{IU})$ and ribavirin $(0.1$ to $100 \mu \mathrm{M})$ for $24 \mathrm{~h}$, cell migration was not influenced (Fig. 2A and 2B, respectively).

\section{Sof-upregulated Genes Were Associated With Cancer Development Of Hcc}

Next-generation sequencing (NGS) of the complete RNA transcriptome (RNA-seq) offers a novel approach to systematically characterize the underlying molecular mechanism of diseases. ${ }^{39-42}$ In OR- 6 cells treated with SOF 1 UM for 24 hours, NGS study was performed and many genes were upregulated by SOF in OR-6 cells. Top-ranked genes were selected for further investigation (Table S1). To further evaluate the clinical meaning of the upregulated genes in patients with HCC, the TCGA database, one of the largest genomic databases available for various cancer types that can be downloaded from an open-access resource, ${ }^{43-45}$ is used for analysis (Table 1). The TCGA data analysis showed that several genes upregulated by SOF in OR-6 cells, including PHOSPHO2, KLHL23, TSNAX-DISC1, TRIM39 and RPP21, were significantly higher in HCC tumor tissues than in non-tumor tissues (Table 1), suggesting that PHOSPHO2, KLHL23, TSNAX-DISC1, TRIM39 and RPP21 were associated with the development of HCC. The association of survival with these SOF-upregulated genes were evaluated by univariate and 
multivariate Cox proportional hazards model. Statistical analysis of the TCGA database found that PHOSPHO2 (Adjusted hazard ratio (AHR) was 1.72, 95\% confidence interval (Cl) was 1.08-2.51 and pvalue was 0.005 ) and RPP21 (AHR was 1.49, 95\% Cl was 1.02-2.18, and p-value was 0.040) were significantly associated with overall survival of HCC, while PHOSPHO2 (AHR was 1.59, 95\% Cl was 1.072.36 and p-value was 0.021 ) was associated with disease-free survival in patients with HCC (Table 2).

Table 1

Comparison of SOF up-regulated genes in tumor versus nontumor parts in HCC

\begin{tabular}{|c|c|c|c|}
\hline \multirow[t]{2}{*}{ Variables } & Non-tumor part & Tumor part & \multirow[t]{2}{*}{ p-value* } \\
\hline & Mean \pm SD & Mean \pm SD & \\
\hline PHOSPHO2 & $4,84 \pm 0.67$ & $5.44 \pm 1.07$ & $\mathbb{\nabla 0 . 0 0 1}$ \\
\hline KLHL23 & $5.67 \pm 1.03$ & $6.25 \pm 2.23$ & 0.049 \\
\hline TSNAX-DISC1 & $0.10 \pm 0.34$ & $0.68 \pm 1.79$ & 0.017 \\
\hline TRIM39 & $8.12 \pm 0.21$ & $8.51 \pm 0.51$ & $\llbracket 0.001$ \\
\hline RPP21 & $8.14 \pm 0.45$ & $8.61 \pm 0.76$ & $\llbracket 0.001$ \\
\hline
\end{tabular}


Table 2

Associated of SOF up-regulated genes with overall survival and disease-free survival of HCC patients

Variable

No. $(\%) \quad$ CHR $(95 \% \mathrm{Cl})$

$p$ value* AHR $(95 \% \mathrm{Cl})$

$p$ value ${ }^{\dagger}$

\section{Overall survival}

\begin{tabular}{lllllll} 
PHOSPHO2 & Low & $242(68.2)$ & 1.00 & & 1.00 & \\
\cline { 2 - 7 } KLHL23 & High & $113(31.8)$ & $1.75(1.23-2.49)$ & 0.002 & $1.72(1.18-2.51)$ & 0.005 \\
\cline { 2 - 7 } & Low & $133(37.5)$ & 1.00 & & 1.00 & \\
\hline TSNAX-DISC1 & Low & $222(62.5)$ & $1.50(1.03-2.19)$ & 0.034 & $1.37(0.93-2.03)$ & 0.115 \\
\cline { 2 - 7 } & High & $69(19.4)$ & $1.08(0.70-1.68)$ & 0.720 & $0.97(0.60-1.58)$ & 0.907 \\
\hline TRIM39 & Low & $247(69.6)$ & 1.00 & & 1.00 & \\
\cline { 2 - 7 } & High & $108(30.4)$ & $1.31(0.91-1.89)$ & 0.148 & $1.32(0.90-1.95)$ & 0.157 \\
\hline RPP21 & Low & $248(69.9)$ & 1.00 & & 1.00 & \\
\cline { 2 - 7 } & High & $107(30.1)$ & $1.28(0.89-1.83)$ & 0.190 & $1.49(1.02-2.18)$ & 0.040
\end{tabular}

\section{Disease-free survival}

\begin{tabular}{|c|c|c|c|c|c|c|}
\hline \multirow[t]{2}{*}{ PHOSPHO2 } & Low & $230(74.2)$ & \multicolumn{2}{|l|}{1.00} & \multicolumn{2}{|l|}{1.00} \\
\hline & High & $80(25.8)$ & $1.43(0.99-2.06)$ & 0.059 & $1.59(1.07-2.36)$ & 0.021 \\
\hline \multirow[t]{3}{*}{ KLHL23 } & Low & $113(36.5)$ & 1.00 & & 1.00 & \\
\hline & High & $197(63.5)$ & $1.43(0.99-2.05)$ & 0.054 & $1.44(0.99-2.11)$ & 0.060 \\
\hline & High & $8(2.6)$ & $1.37(0.56-3.35)$ & 0.491 & $1.01(0.37-2.77)$ & 0.979 \\
\hline \multirow[t]{3}{*}{ TSNAX-DISC1 } & Low & $249(80.3)$ & 1.00 & & 1.00 & \\
\hline & High & 61 (19.7) & $1.23(0.82-1.85)$ & 0.311 & $1.27(0.83-1.94)$ & 0.277 \\
\hline & High & $59(19.0)$ & $1.24(0.83-1.85)$ & 0.294 & $1.23(0.81-1.87)$ & 0.338 \\
\hline \multirow[t]{2}{*}{ TRIM39 } & Low & $272(87.7)$ & 1.00 & & 1.00 & \\
\hline & High & 38 (12.3) & $1.20(0.75-1.91)$ & 0.441 & $0.97(0.59-1.62)$ & 0.914 \\
\hline \multirow[t]{2}{*}{ RPP21 } & Low & 165 (53.2) & 1.00 & & 1.00 & \\
\hline & High & $145(46.8)$ & $1.37(0.97-1.92)$ & 0.071 & $1.31(0.92-1.86)$ & 0.142 \\
\hline
\end{tabular}


Abbreviations:HCC, hepatocellulasr carcinoma ;CHR, crude hazard ratio; $\mathrm{Cl}$, confidence interval; $\mathrm{AHR}$, adjusted hazard ratio; AJCC, American Joint Committee on Cancer;

${ }^{\dagger} p$ values were adjusted for cell differentiation (moderate + poor vs. well) and AJCC pathological stage (stage III + IV vs stage I + II) by multivariate Cox's regression

\section{Silencing Upregulated Genes Reduced Sof-mediated Cell Proliferation And Migration}

NGS studies revealed that several genes including PHOSPHO2-KLHL23, TSNAX-DISC1, TRIM39, RPP21 were upregulated by SOF in OR-6 cells and were associated with the development of HCC according to the TCGA database. These upregulated genes in OR-6 cells were evaluated using Q-PCR. Results indicated that PHOSPHO2-KLHL23, TSNAX-DISC1, TRIM39 and RPP21 were significantly upregulated by SOF in OR-6 cells (Fig. 3).

Previous results showed that SOF increased two- and three-dimensional cell proliferation in hepatoma cells with or without HCV infection (Fig. 1A and 1B, respectively). Furthermore, PHOSPHO2-KLHL23, TSNAX-DISC1, TRIM39 and RPP21, which were upregulated by SOF in OR-6 cells, were associated with the development of HCC according to the TCGA database (Table 2). The effects of these genes on SOFenhanced cell proliferation remained unknown. Knockdown of PHOSPHO2-KLHL23, TSNAX-DISC1, TRIM39 and RPP21 with siRNA ameliorated SOF-elevated cell proliferation in OR-6 and Huh7.5.1 cells in both two- and three-dimensional cultures (Fig. 4). The present results indicated that PHOSPHO2-KLHL23, TSNAX-DISC1, TRIM39 and RPP21 were associated with cell proliferation in SOF-treated hepatoma cells with and without HCV infection.

In addition, the association of these genes with SOF-enhanced cell migration also remained unknown. siRNA-mediated knockdown of PHOSPHO2-KLHL23, TSNAX-DISC1, TRIM39 and RPP21 indicated that the increase in cell migration by SOF was reduced in OR-6 and Huh7.5.1 cells when transfected with siRNA against these genes (Fig. 5). Current findings suggested that PHOSPHO2-KLHL23, TSNAX-DISC1, TRIM39 and RPP21 were associated with cell migration in SOF-treated hepatoma cells with and without HCV infection.

\section{Discussion}

Direct-acting antivirals (DAAs) have achieved a sustained virological response (SVR) rate of $95-98 \%$ in treating HCV. Several studies suggested that treatment with DAAs may be associated with increased risk of developing HCC in the first 6-12 months. ${ }^{21-23}$ The molecular mechanisms of how DAAs increased the development of HCC have been investigated in several studies. ${ }^{27-32}$ However, the involvement of SOF in tumor development of HCC remains unclear. This study obtained the following findings. First, SOF 
increased cell proliferation and metastatic characteristics in HCC cells with or without HCV virus. Second, NGS and TCGA data analysis revealed that several SOF-upregulated genes, including PHOSPHO2KLHL23, TSNAX-DISC1, TRIM39 and RPP21, were also elevated in tumor tissues compared with nontumor tissues in patients with HCC. Third, knockdown of these genes ameliorated SOF-mediated cell proliferation and migration. The present results imply that SOF might upregulate these genes to facilitate tumor development of HCC.

SOF is the inhibitor of NS5B of HCV. The NS5B of HCV is $68 \mathrm{kD}$ a tail-anchored protein with $21 \mathrm{C}$-terminal amino acids alpha helical trans-membrane domain. ${ }^{46}$ NS5B RNA-dependent RNA polymerase (RdRp) is the key component of the replicative complex and is important for viral RNA replication and initiation. ${ }^{47}$, ${ }^{48}$ However, the clinical significance of SOF-upregulated genes in the carcinogenesis of HCC is largely unknown. This study found that several genes including PHOSPHO2, KLHL23, TSNAX-DISC1, TRIM39 and RPP21 were upregulated by SOF and the expression levels of these genes were higher in tumor tissues than in non-tumor tissues of patients with HCC according to the TCGA database. The present results indicated that several SOF-upregulated genes including PHOSPHO2-KLHL23, TSNAX-DISC1, TRIM39 and RPP21 were associated with the development of HCC. Moreover, the findings also demonstrated that high expression of Phospho2 and RPP21 were correlated with poor overall survival of HCC, while high expression of Phospho2 was associated with disease-free survival. Silencing SOFupregulated genes reduced significantly elevated cell proliferation and migration of HCC cells stimulated by SOF. Taken together, the SOF-upregulated genes may contribute to the development of HCC, the overall survival and disease-free survival of HCC. The present results may offer an explanation for the unexpected high recurrence rate of $\mathrm{HCC}$ in $\mathrm{CHC}$ patients undergoing DAA treatment. ${ }^{21-23}$

This study also found that SOF increased cell proliferation and migration in hepatoma cells with or without HCV infection, while knockdown of PHOSPHO2-KLHL23, TSNAX-DISC1, TRIM39 and RPP21 reduced the increase in cell proliferation and migration by SOF in OR-6 (HCV-positive HCC cell line) and Huh 7.5.1 (HCV-negative HCC cell line) cells. Enhanced cell proliferation and migration were essential for tumor carcinogenesis. The present findings suggested that several SOF-upregulated genes were associated with tumor growth and metastatic characteristics, which might be involved in the development of HCC and unfavorable prognosis regardless whether the cells are infected with HCV or not. This is the first study indicating that SOF may be involved in the carcinogens of HCC via its upregulated genes.

Cured OR-6 cells using either Interferon-a or DAA may actually influence the phenotype of OR-6 cells. Interferon-a or DAA treated OR- 6 cells were not a good model for the study of SOF upregulated genes in OR-6 cells so experiments on cured OR-6 cells were not performed.

Although OR-6 and Huh 7.5.1 cells have a cancer phenotype, this study found that several genes including PHOSPHO2, KLHL23, TSNAX-DISC1, TRIM39 and RPP21 were upregulated by SOF in OR-6 cells and the expression levels of these genes were higher in tumor tissues than in non-tumor tissues of patients with HCC according to the TCGA database. PHOSPHO2 and RPP21 were also found to be associated with overall survival of HCC patients in the TCGA database. Data from TCGA database, a 
human cancer database has confirmed our results and the prognostic roles of these were also revealed. And actually, recurrence of $\mathrm{HCC}$ was unexpectedly high among $\mathrm{CHC}$ patients with history of $\mathrm{HCC}$ treated with DAA[21, 22].

Several studies associated the candidate genes upregulated by SOF with carcinogenesis. A recent study found that overexpression of KLHL23 protein from read-through transcription of PHOSPHO2-KLHL23 increased cell proliferation in gastric cancer cells[49]. Another study found that lincRNA-NR_034037 regulated TSNAX-DISC1 formation programs that tightly regulate endometrial carcinoma development[50]. Trim39 was also found to be a biomarker for early detection of ovarian cancer[51] and to regulate cell cycle progression and DNA damage responses[52]. The DNA damage signature including RPP21 can be employed to define a group of patients of prostate cancer with poor outcome and has the potential to be used as a prognostic marker in treatment. ${ }^{53}$ Taken together, the SOF-upregulated genes have been found to be related to carcinogenesis in several cancers. Nevertheless, the detailed mechanisms of how these genes modulate HCC development require further experiments to elucidate.

\section{Conclusions}

Results of this study suggested association of several SOF-upregulated genes with increased cell proliferation and migration, which may contribute to development of HCC.

\section{Abbreviations}

HCV, hepatitis C virus; $\mathrm{CHC}$, chronic hepatitis C; SOF, sofosbuvir; SVR, sustained virological response; DAA, Direct-acting antivirals; HCC, hepatocellular carcinoma; TCGA, The Cancer Genome Atlas; NGS, next generation sequencing

\section{Declarations}

\section{Ethics approval and consent to participate}

The human samples were not used in this study.

\section{Consent for publication}

The consent forms were signed by every participant and will be provided upon request.

\section{Availability of data and materials}

The datasets used and/or analyzed during the current study were available from the corresponding authors on reasonable request. 


\section{Competing interests}

Authors declare that there is no conflict of interests

\section{Funding}

This study was supported by Ministry of Science and Technology of Taiwan, MOST (107-2314-B-075B$002-M Y 2)$.

\section{Authors' contributions}

WLT and CWS designed research studies, conducted experiments, analyzed data and wrote the manuscript. PFL and THC conducted experiments and analyzed data. YYC conducted experiments. JSC, WCS and WCC edited the manuscript.

\section{Acknowledgements}

No acknowledgements

\section{References}

1. Kao JH, Chen DS. Changing disease burden of hepatocellular carcinoma in the Far East and Southeast Asia. Liver Int. 2005;25:696-703.

2. Yu ML, Chen PJ, Dai CY, Hu TH, Huang CF, Huang YH, et al. 2020 Taiwan consensus statement on the management of hepatitis C: part (I) general population. J Formos Med Assoc. 2020;119:1019-40.

3. Sarin SK, Kumar M, Eslam M, George J, Al Mahtab M, Akbar SMF, et al. Liver diseases in the AsiaPacific region: a Lancet Gastroenterology \& Hepatology Commission. Lancet Gastroenterol Hepatol. 2020;5:167-228.

4. Fattovich G, Stroffolini T, Zagni I, Donato F. Hepatocellular carcinoma in cirrhosis: incidence and risk factors. Gastroenterology. 2004;127:35-50.

5. Scheel TK, Rice CM. Understanding the hepatitis $C$ virus life cycle paves the way for highly effective therapies. Nat Med. 2013;19:837-49.

6. Thomas DL. Global control of hepatitis C: where challenge meets opportunity. Nat Med. 2013;19:850-8.

7. Wakita T, Pietschmann T, Kato T, Date T, Miyamoto M, Zhao Z, et al. Production of infectious hepatitis C virus in tissue culture from a cloned viral genome. Nat Med. 2005;11:791-6.

8. Schaefer EA, Chung RT. Anti-hepatitis C virus drugs in development. Gastroenterology. 2012;142:1340-50.e1341.

9. Vermehren J, Park JS, Jacobson IM, Zeuzem S. Challenges and perspectives of direct antivirals for the treatment of hepatitis C virus infection. J Hepatol. 2018;69:1178-87. 
10. European Association for the Study of the Liver. EASL Recommendations on Treatment of Hepatitis C 2018. J Hepatol. 2018;69:461-511.

11. AASLD-IDSA HCV Guidance Panel. Hepatitis CG. 2018 Update: AASLD-IDSA Recommendations for Testing, Managing, and Treating Hepatitis C Virus Infection. Clin Infect Dis 2018;67:1477-1492.

12. Pearlman BL, Hinds AE. Review article: novel antivirals for hepatitis Csofosbuvir/velpatasvir/voxilaprevir, glecaprevir/pibrentasvir. Aliment Pharmacol Ther. 2018;48:91423.

13. Milani A, Basimi P, Agi E, Bolhassani A. Pharmaceutical Approaches for Treatment of Hepatitis C Virus. Curr Pharm Des. 2020;26:4304-14.

14. Kowdley KV, Gordon SC, Reddy KR, Rossaro L, Bernstein DE, Lawitz E, et al. Ledipasvir and sofosbuvir for 8 or 12 weeks for chronic HCV without cirrhosis. N Engl J Med. 2014;370:1879-88.

15. Afdhal N, Zeuzem S, Kwo P, Chojkier M, Gitlin N, Puoti M, et al. Ledipasvir and sofosbuvir for untreated HCV genotype 1 infection. N Engl J Med. 2014;370:1889-98.

16. Foster GR, Afdhal N, Roberts SK, Bräu N, Gane EJ, Pianko S, et al. Sofosbuvir and Velpatasvir for HCV Genotype 2 and 3 Infection. N Engl J Med. 2015;373:2608-17.

17. Curry MP, O'Leary JG, Bzowej N, Muir AJ, Korenblat KM, Fenkel JM, et al. Sofosbuvir and Velpatasvir for HCV in Patients with Decompensated Cirrhosis. N Engl J Med. 2015;373:2618-28.

18. Romano A, Angeli P, Piovesan S, Noventa F, Anastassopoulos G, Chemello L, et al. Newly diagnosed hepatocellular carcinoma in patients with advanced hepatitis $C$ treated with DAAs: A prospective population study. J Hepatol. 2018;69:345-52.

19. Ono A, Goossens N, Finn RS, Schmidt WN, Thung SN, Im GY, et al. Persisting risk of hepatocellular carcinoma after hepatitis $\mathrm{C}$ virus cure monitored by a liver transcriptome signature. Hepatology. 2017;66:1344-6.

20. Shiha G, Mousa N, Soliman R, Nnh Mikhail N, Adel Elbasiony M, Khattab M. Incidence of HCC in chronic hepatitis $\mathrm{C}$ patients with advanced hepatic fibrosis who achieved SVR following DAAs: A prospective study. J Viral Hepat. 2020;27:671-9.

21. Reig M, Mariño Z, Perelló C, Iñarrairaegui M, Ribeiro A, Lens S, et al. Unexpected high rate of early tumor recurrence in patients with HCV-related HCC undergoing interferon-free therapy. J Hepatol. 2016;65:719-26.

22. Conti F, Buonfiglioli F, Scuteri A, Crespi C, Bolondi L, Caraceni P, et al. Early occurrence and recurrence of hepatocellular carcinoma in HCV-related cirrhosis treated with direct-acting antivirals. $\mathrm{J}$ Hepatol. 2016;65:727-33.

23. Calleja JL, Crespo J, Rincón D, Ruiz-Antorán B, Fernandez I, Perelló C, et al. Effectiveness, safety and clinical outcomes of direct-acting antiviral therapy in HCV genotype 1 infection: Results from a Spanish real-world cohort. J Hepatol. 2017;66:1138-48.

24. ANRS collaborative study group on hepatocellular carcinoma. Lack of evidence of an effect of directacting antivirals on the recurrence of hepatocellular carcinoma: Data from three ANRS cohorts. J Hepatol. 2016;65:734-40. 
25. Li DK, Ren Y, Fierer DS, Rutledge S, Shaikh OS, Lo Re V. 3rd, et al. The short-term incidence of hepatocellular carcinoma is not increased after hepatitis $C$ treatment with direct-acting antivirals: An ERCHIVES study. Hepatology 2018;67:2244-53.

26. Kanwal F, Kramer J, Asch SM, Chayanupatkul M, Cao Y, El-Serag HB. Risk of Hepatocellular Cancer in HCV Patients Treated With Direct-Acting Antiviral Agents. Gastroenterology. 2017;153:9961005.e1001.

27. Villani R, Facciorusso A, Bellanti F, Tamborra R, Piscazzi A, Landriscina M, et al. DAAs Rapidly Reduce Inflammation but Increase Serum VEGF Level: A Rationale for Tumor Risk during Anti-HCV Treatment. PLoS One. 2016;11:e0167934.

28. Bojkova D, Westhaus S, Costa R, Timmer L, Funkenberg N, Korencak M, et al. Sofosbuvir Activates EGFR-Dependent Pathways in Hepatoma Cells with Implications for Liver-Related Pathological Processes. Cells. 2020;9:1003.

29. Debes JD, van Tilborg M, Groothuismink ZMA, Hansen BE, Schulze Zur Wiesch J, von Felden J, et al. Levels of Cytokines in Serum Associate With Development of Hepatocellular Carcinoma in Patients With HCV Infection Treated With Direct-Acting Antivirals. Gastroenterology. 2018;154:515-7.e513.

30. Chu PS, Nakamoto N, Taniki N, Ojiro K, Amiya T, Makita Y, et al. On-treatment decrease of NKG2D correlates to early emergence of clinically evident hepatocellular carcinoma after interferon-free therapy for chronic hepatitis C. PLoS One. 2017;12:e0179096.

31. Hengst J, Falk CS, Schlaphoff V, Deterding K, Manns MP, Cornberg M, et al. Direct-Acting AntiviralInduced Hepatitis C Virus Clearance Does Not Completely Restore the Altered Cytokine and Chemokine Milieu in Patients With Chronic Hepatitis C. J Infect Dis. 2016;214:1965-74.

32. Perez S, Kaspi A, Domovitz T, Davidovich A, Lavi-Itzkovitz A, Meirson T, et al. Hepatitis C virus leaves an epigenetic signature post cure of infection by direct-acting antivirals. PLoS Genet. 2019;15:e1008181.

33. Ikeda M, Abe K, Dansako H, Nakamura T, Naka K, Kato N. Efficient replication of a full-length hepatitis $\mathrm{C}$ virus genome, strain $\mathrm{O}$, in cell culture, and development of a luciferase reporter system. Biochem Biophys Res Commun. 2005;329:1350-9.

34. Cheng JS, Tsai WL, Liu PF, Goan YG, Lin CW, Tseng HH, et al. The MAP3K7-mTOR Axis Promotes the Proliferation and Malignancy of Hepatocellular Carcinoma Cells. Front Oncol. 2019;9:474.

35. Bruno S, Battezzati PM, Bellati G, Manzin A, Maggioni M, Crosignani A, et al. Long-term beneficial effects in sustained responders to interferon-alfa therapy for chronic hepatitis C. J Hepatol. 2001;34:748-55.

36. Veldt BJ, Saracco G, Boyer N, Cammà C, Bellobuono A, Hopf U, et al. Long term clinical outcome of chronic hepatitis $C$ patients with sustained virological response to interferon monotherapy. Gut. 2004;53:1504-8.

37. Bruno S, Stroffolini T, Colombo M, Bollani S, Benvegnù L, Mazzella G, et al. Sustained virological response to interferon-alpha is associated with improved outcome in HCV-related cirrhosis: a retrospective study. Hepatology. 2007;45:579-87. 
38. van der Meer AJ, Veldt BJ, Feld JJ, Wedemeyer H, Dufour JF, Lammert F, et al. Association between sustained virological response and all-cause mortality among patients with chronic hepatitis $\mathrm{C}$ and advanced hepatic fibrosis. JAMA. 2012;308:2584-93.

39. Ozsolak F, Milos PM. RNA sequencing: advances, challenges and opportunities. Nat Rev Genet. 2011;12:87-98.

40. Wang Z, Gerstein M, Snyder M. RNA-Seq: a revolutionary tool for transcriptomics. Nat Rev Genet. 2009;10:57-63.

41. Sultan M, Schulz MH, Richard H, Magen A, Klingenhoff A, Scherf $M$, et al. A global view of gene activity and alternative splicing by deep sequencing of the human transcriptome. Science. 2008;321:956-60.

42. Mi N, Cao J, Zhang J, Fu W, Huang C, Gao L, et al. Identification of hub genes involved in the occurrence and development of hepatocellular carcinoma via bioinformatics analysis. Oncol Lett. 2020;20:1695-708.

43. Matsushita J, Suzuki T, Okamura K, Ichihara G, Nohara K. Identification by TCGA database search of five genes that are aberrantly expressed and involved in hepatocellular carcinoma potentially via DNA methylation changes. Environ Health Prev Med. 2020;25:31.

44. Liu Z, Lin Y, Gao X, Mai R, Piao X, Ye J, et al. Construction of a Comprehensive Multiomics Map of Hepatocellular Carcinoma and Screening of Possible Driver Genes. Front Genet. 2020;11:634.

45. Tao H, Li Z, Mei Y, Li X, Lou H, Dong L, et al. Integrative bioinformatics analysis of a prognostic index and immunotherapeutic targets in renal cell carcinoma. Int Immunopharmacol. 2020;87:106832.

46. Suzuki T, Ishii K, Aizaki H, Wakita T. Hepatitis C viral life cycle. Adv Drug Deliv Rev. 2007;59:1200-12.

47. De Francesco R, Carfí A. Advances in the development of new therapeutic agents targeting the NS34A serine protease or the NS5B RNA-dependent RNA polymerase of the hepatitis C virus. Adv Drug Deliv Rev. 2007;59:1242-62.

48. Elfiky AA, Elshemey WM, Gawad WA, Desoky OS. Molecular modeling comparison of the performance of NS5b polymerase inhibitor (PSI-7977) on prevalent HCV genotypes. Protein J. 2013;32:75-80.

49. Choi ES, Lee H, Lee $\mathrm{CH}$, Goh SH. Overexpression of KLHL23 protein from read-through transcription of PHOSPHO2-KLHL23 in gastric cancer increases cell proliferation. FEBS Open Bio. 2016;6:115564.

50. Li N, Zheng J, Li H, Deng J, Hu M, Wu H, et al. Identification of chimeric TSNAX-DISC1 resulting from intergenic splicing in endometrial carcinoma through high-throughput RNA sequencing. Carcinogenesis. 2014;35:2687-97.

51. Fortner RT, Damms-Machado A, Kaaks R. Systematic review: Tumor-associated antigen autoantibodies and ovarian cancer early detection. Gynecol Oncol. 2017;147:465-80.

52. Zhang L, Mei Y, Fu NY, Guan L, Xie W, Liu HH, et al. TRIM39 regulates cell cycle progression and DNA damage responses via stabilizing p21. Proc Natl Acad Sci U S A. 2012;109:20937-42. 
53. ddawela M, Pazaro C, Lawrence M, Furic L, Taylor R, Risbridger G. Association of "DNA damage signature" with poor outcome in early prostate cancer. J Clin Oncol. 2015;33:13.

\section{Figures}
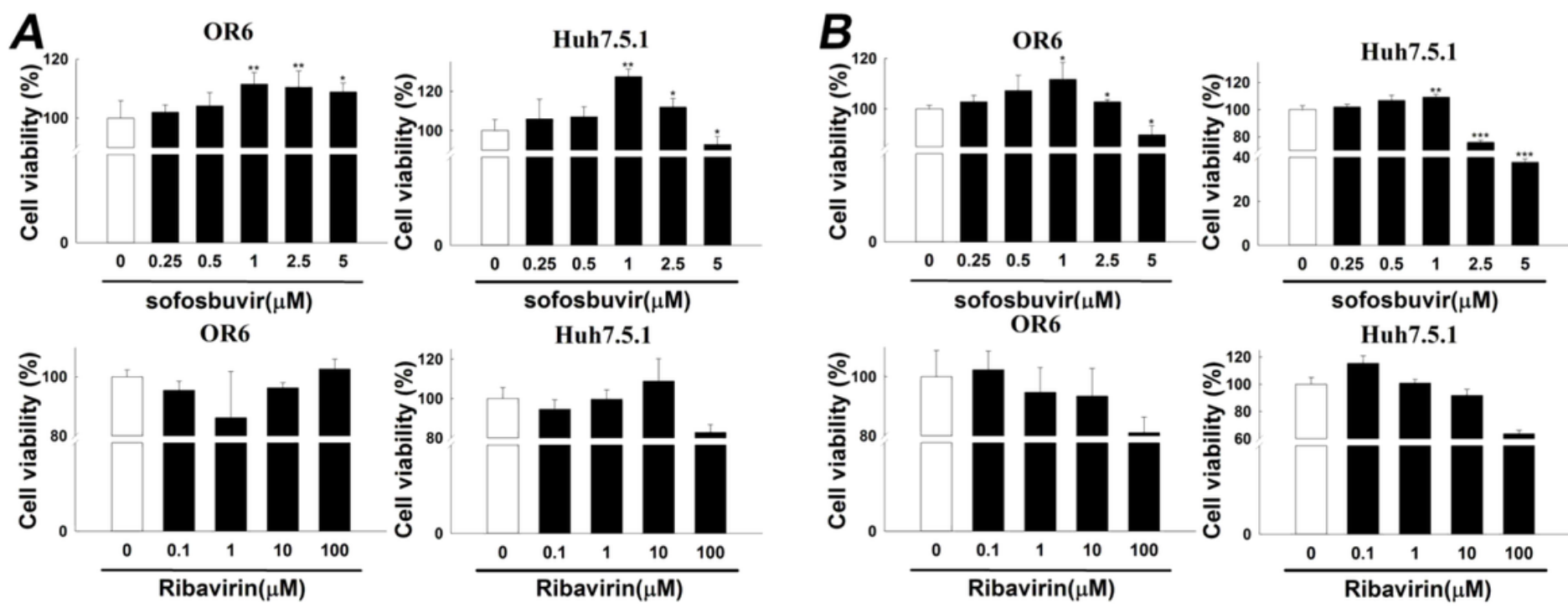

Huh7.5.1
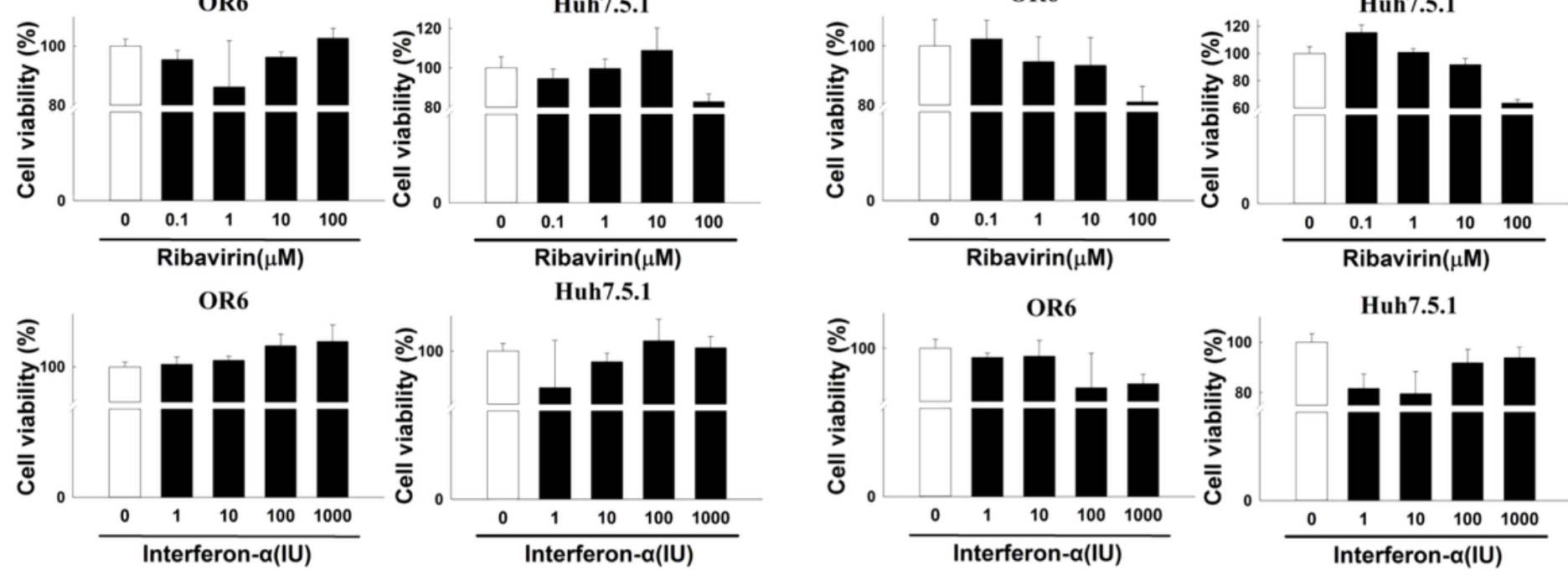

Huh7.5.1

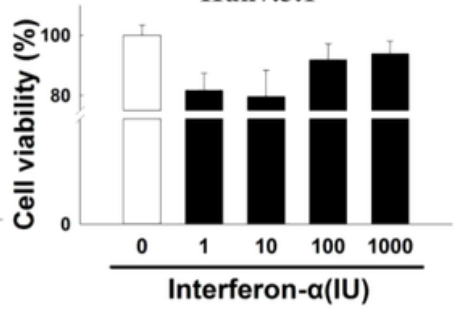

Figure 1

The effects of sofosbuvir, ribavirin and interferon- $a$ on cell proliferation in HCC cells. (A)Two-dimensional cell proliferation assay in OR-6 and Huh 7.5.1 cells treated with different doses of SOF $(0.25$ to $5 \mu \mathrm{M})$, interferon-a (1 to $1000 \mathrm{IU})$ and ribavirin $(0.1$ to $100 \mu \mathrm{M})$ for 24 hrs were performed. (B) The OR-6 and Huh 7.5.1 cells were grown in three-dimensional culture dish and treated with different doses of SOF $(0.25$ to $5 \mu \mathrm{M})$, interferon-a (1 to $1000 \mathrm{IU})$ and ribavirin $(0.1$ to $100 \mu \mathrm{M})$ for $24 \mathrm{hrs}$ to inspect cell proliferation. The experiments were performed from three independent experiments. $\left({ }^{\star} p<0.05 ;{ }^{*} p<0.01 ;{ }^{* \star} p<0.001\right)$. 
$\boldsymbol{A}$

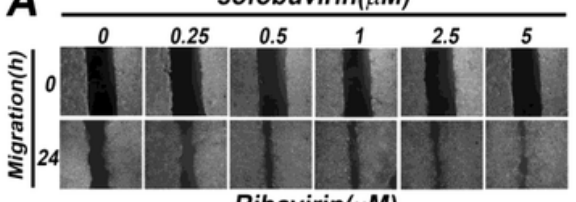

Ribavirin $(\mu M)$
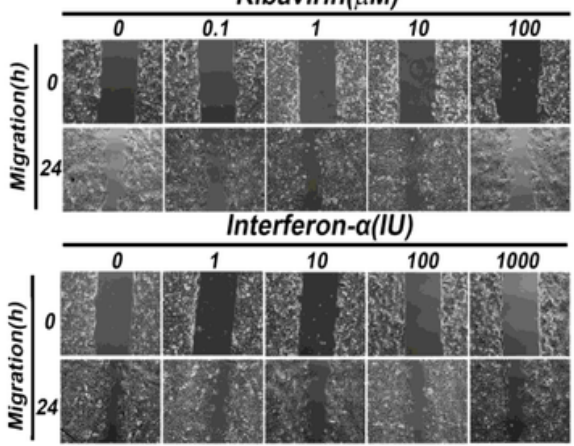

B

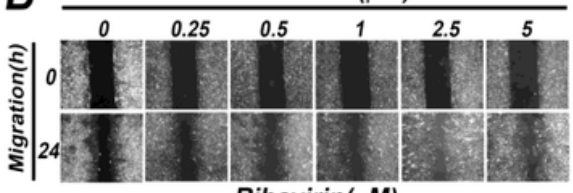

Ribavirin $(\mu \mathrm{M})$

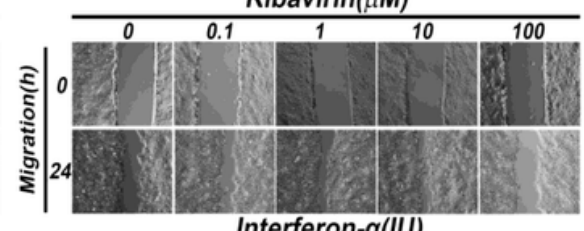

Interferon- $\alpha($ IU)

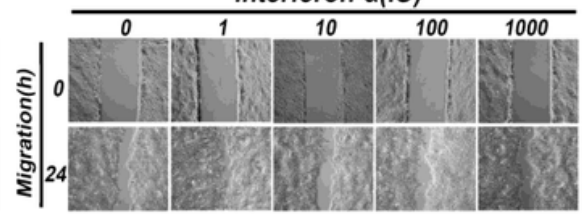

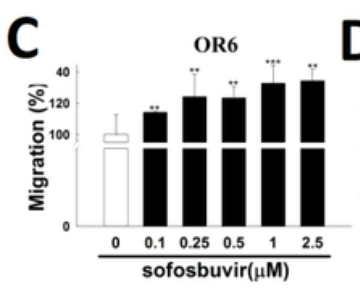
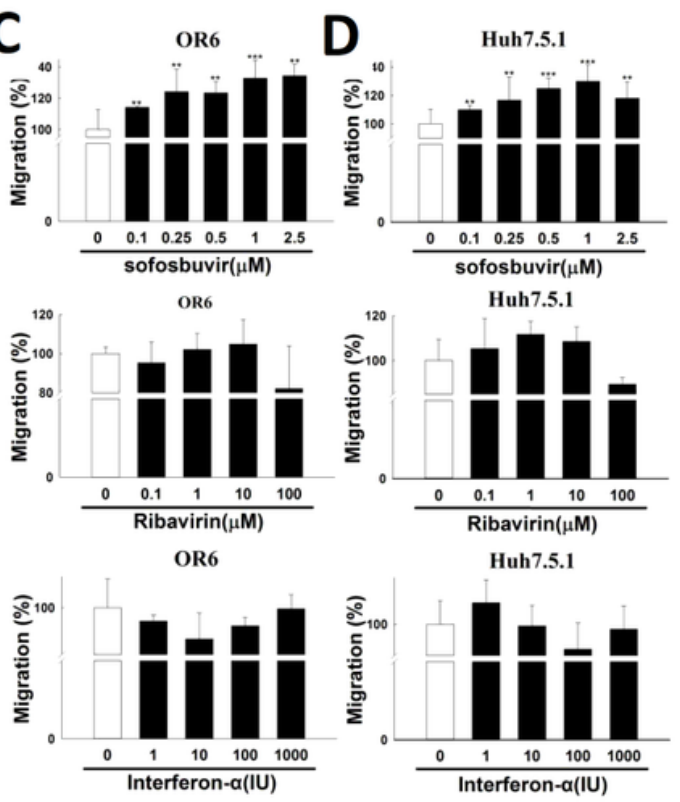

Figure 2

Cell migration assay in sofosbuvir treated hepatoma cells. Interferon-a and ribavirin served as controls.

Cell migration assay was performed in OR- 6 cells $(A)$ and Huh 7.5.1 cells (B) treated with different doses of SOF $(0.1$ to $2.5 \mu \mathrm{M})$, interferon-a (1 to $1000 \mathrm{IU})$ and ribavirin $(0.1$ to $100 \mu \mathrm{M})$ for $24 \mathrm{hrs}$ in the left panel. The quantitative results for migratory distance of (C) OR-6 cells or (D) Huh7.5.1 were calculated with Image $J$ software and expressed as the mean \pm SEM from three independent experiments. $\left({ }^{\star} p<0.05 ; * \star p<\right.$ $0.01 ; \quad * \star *<0.001)$. 


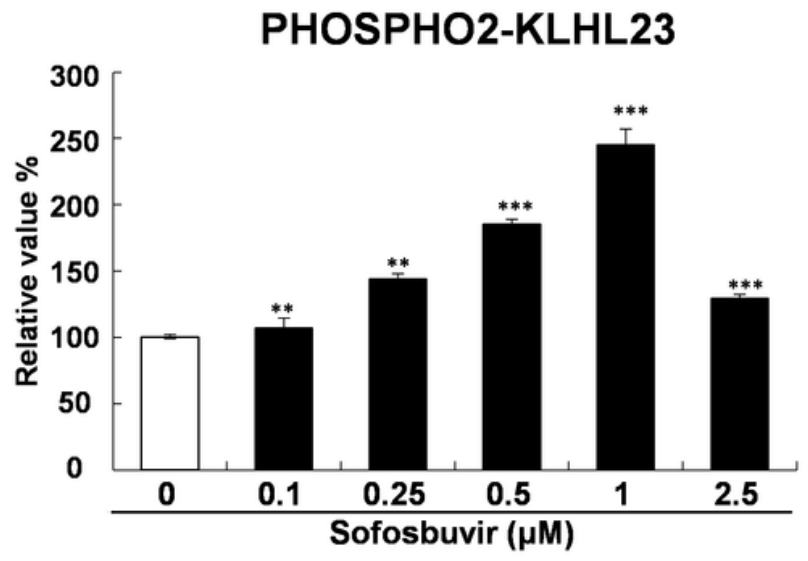

TRIM39

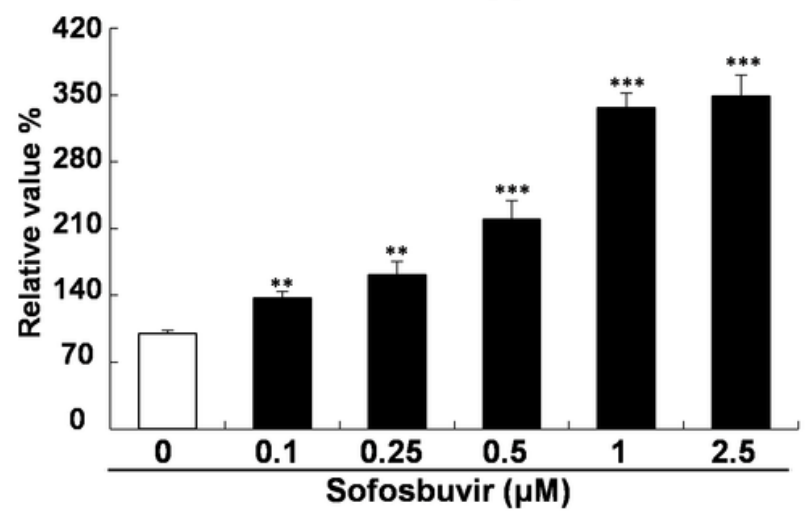

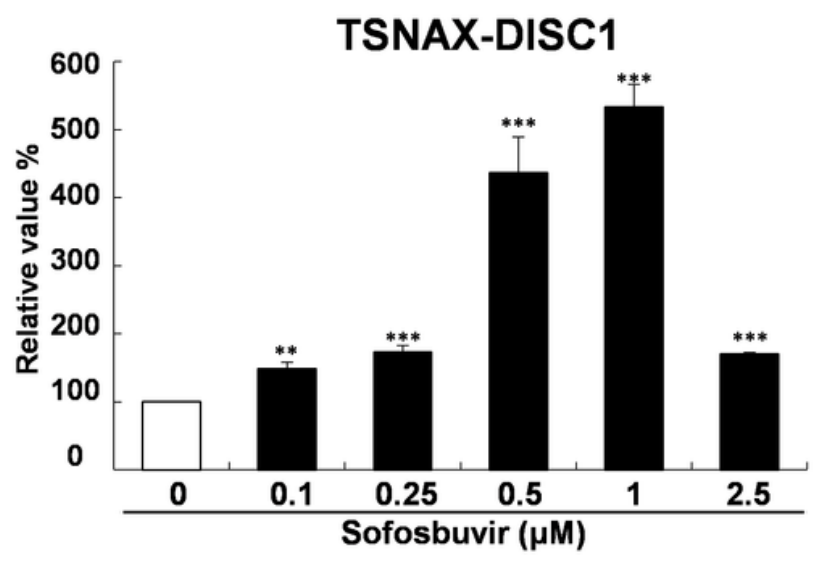

RPP21

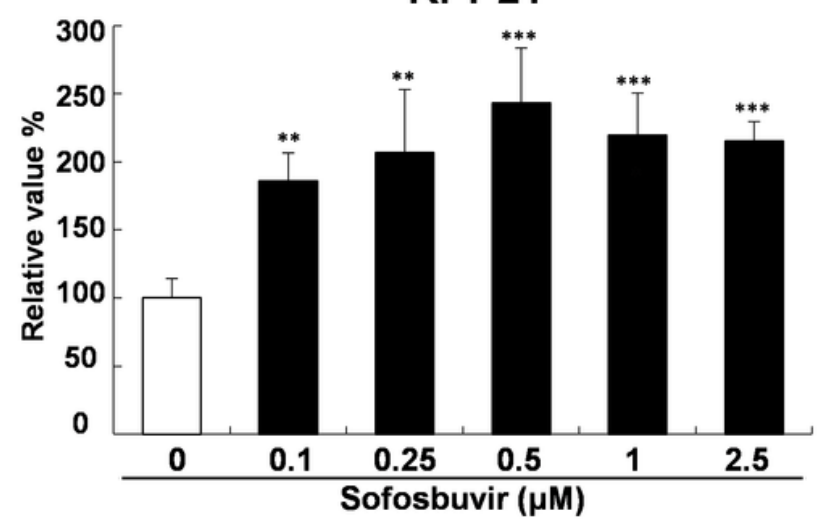

Figure 3

Validation of candiate genes up-regulated by SOF. To avalidate the SOF-upregulated genes identified from NGS, the OR-6 cells were treated with SOF $(0.1$ to $2.5 \mu \mathrm{M})$ for $24 \mathrm{hrs}$. The cells were harvested to determine gene expression with Q-PCR. Q-PCR validation of Phospho2-KLHL23, TSNAX-DISC1, TRIM39, RPP21 in OR- 6 cells were performed using GAPDH as a normalized control. The experiments were performed from three independent experiments. $\left({ }^{\star} p<0.05 ; * \star p<0.01 ; * \star * p<0.001\right)$. 
A

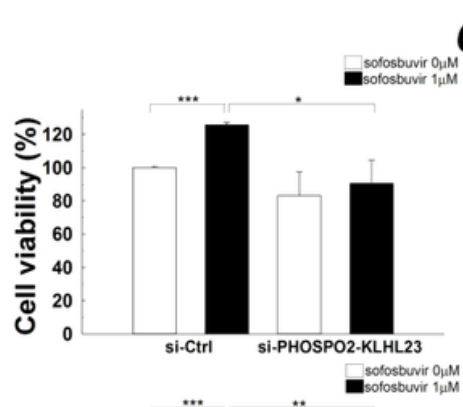

\section{OR6}
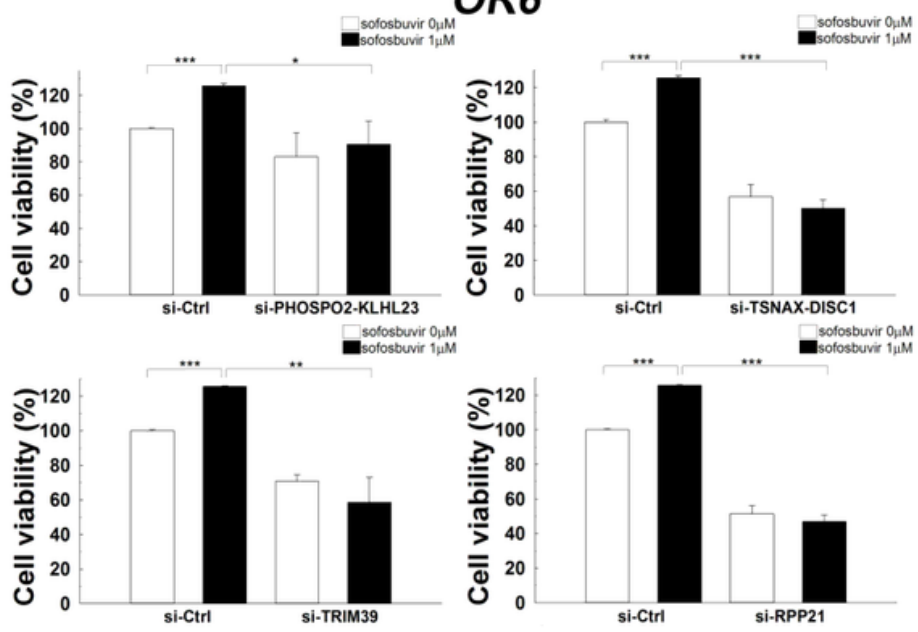

C

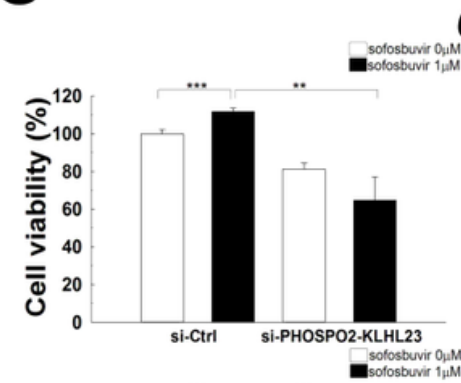

\section{OR6}
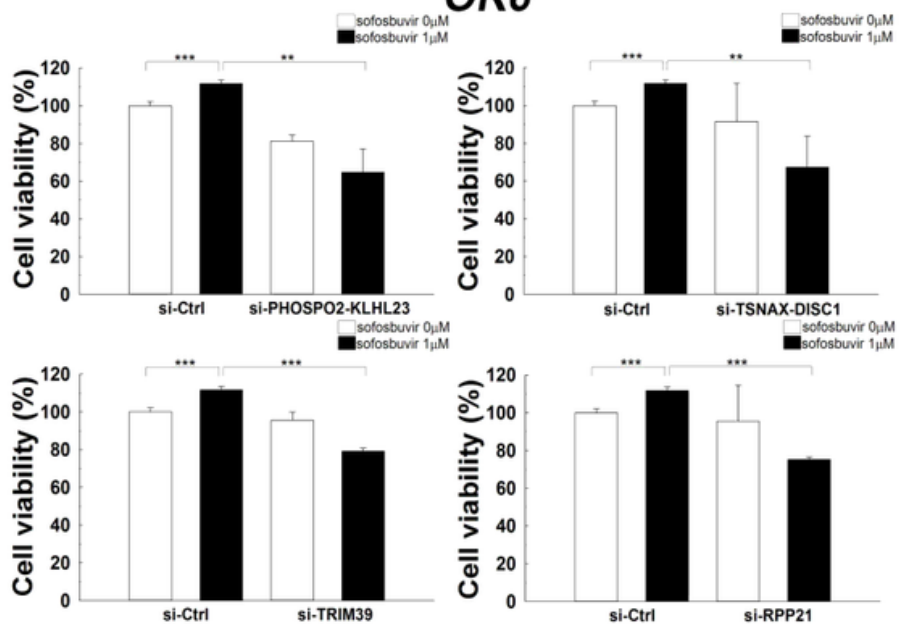

B

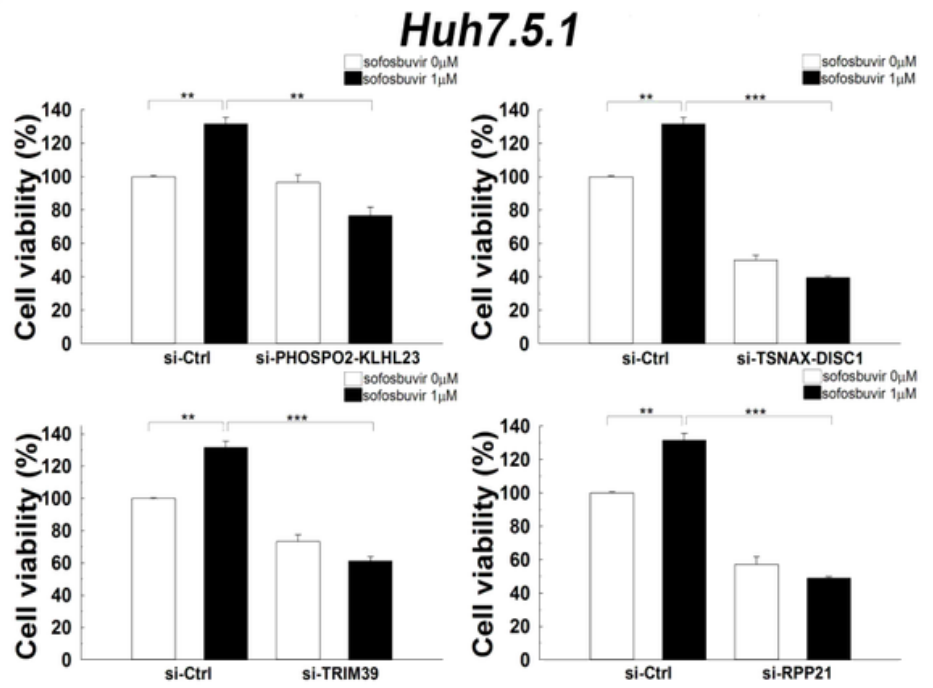

D

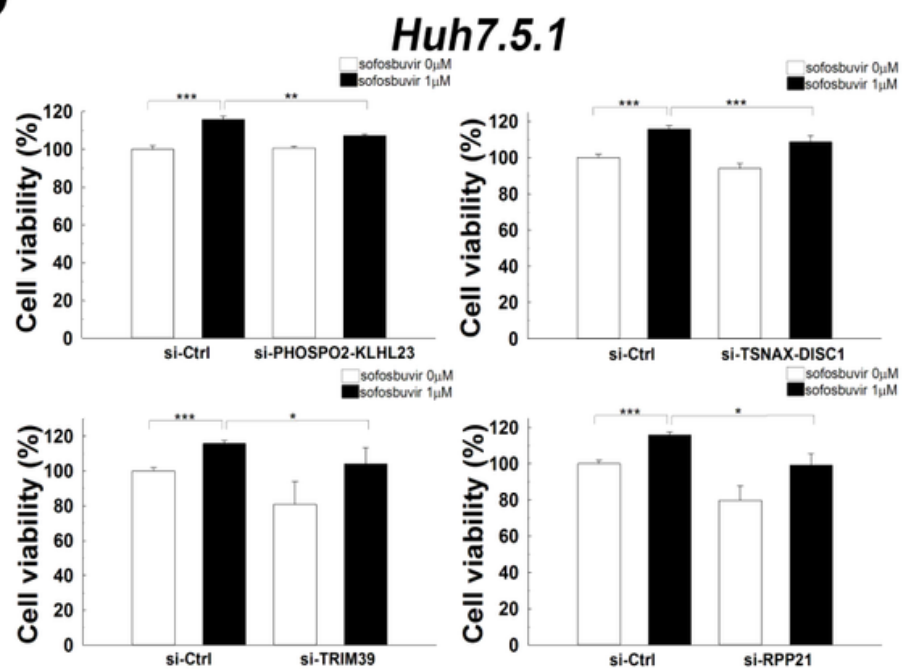

Figure 4

Effects of siRNA against candidate genes on cell proliferation assay in SOF treated OR-6 and Huh 7.5.1 cells. OR-6 (A, C) and Huh 7.5.1 (B, D) cells were transfected with non-targeting siRNA (si-Ctrl) or siRNA against Phospho2-KLHL23, TSNAX-DISC1, TRIM39 and RPP21 for 48 hrs. The cells were then treated with SOF $1 \mu \mathrm{M}$ for $24 \mathrm{hrs}$. The ATP level in cells were accessed to measure cell proliferation $(\mathrm{A}, \mathrm{B})$. In addition, the cells were seeded on $3 \mathrm{D}$ culture plates to form tumorsphere in the presence or absence of 1 $\mu \mathrm{M}$ SOF for $24 \mathrm{hrs}$. The experiments were performed from three independent experiments. $\left({ }^{*} \mathrm{p}<0.05\right.$; $\star \star \mathrm{p}<0.01 ; \quad * \star \star \mathrm{p}<0.001)$. 

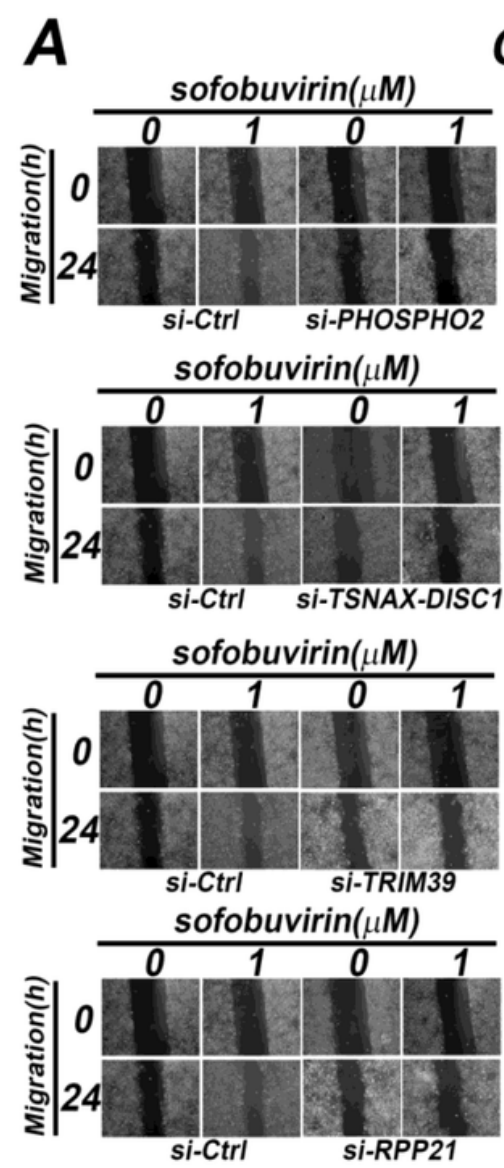

OR6
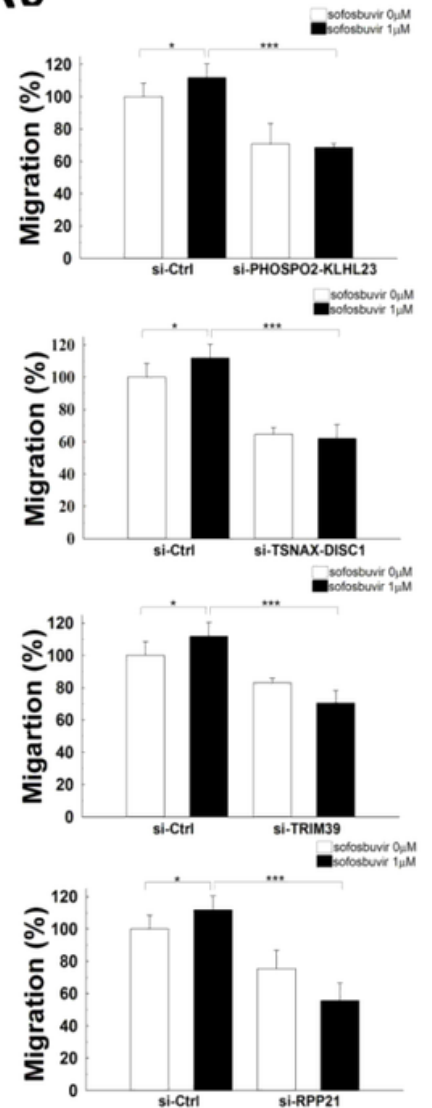

B

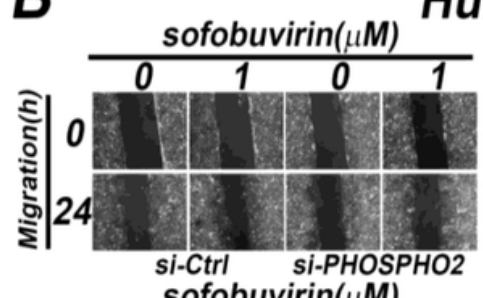
sofobuvirin $(\mu M)$
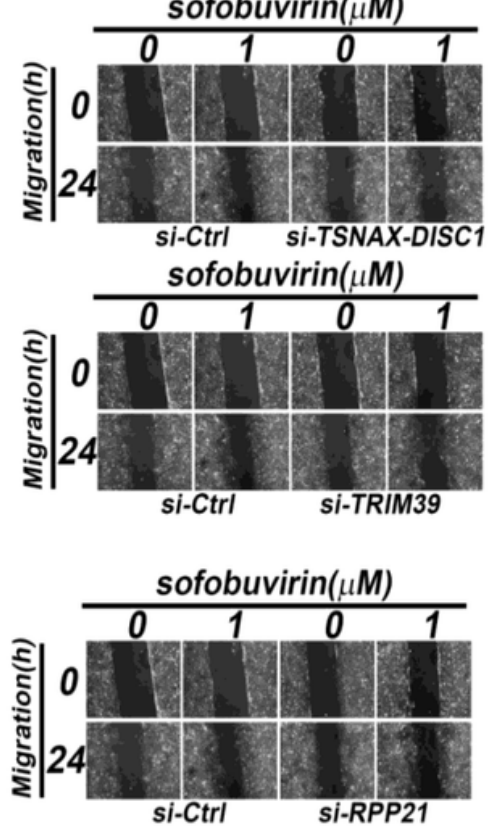
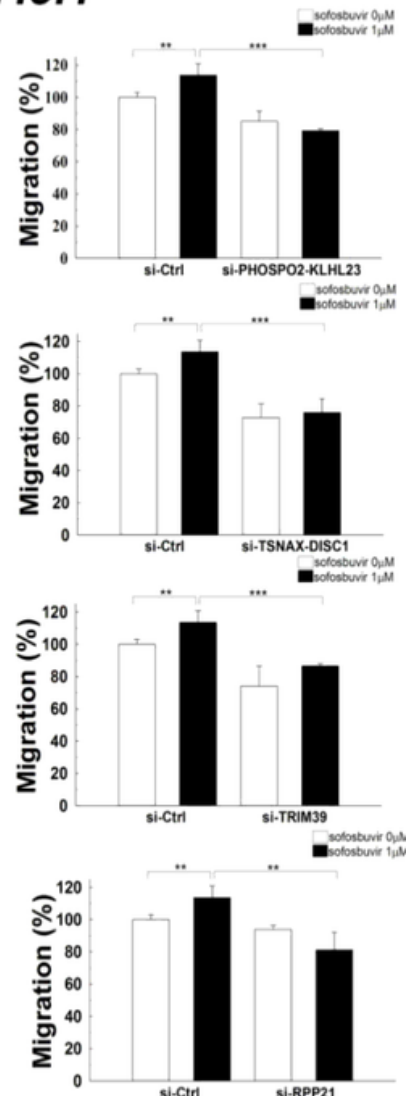

Figure 5

Effects of siRNA against candidate genes on cell migration in SOF treated OR-6 and Huh 7.5.1 cells. OR-6 (A) and Huh 7.5.1 cells (B) were transfected with non-targeting siRNA (si-Ctrl) or siRNA against Phospho2KLHL23, TSNAX-DISC1, TRIM39 and RPP21 for 48 hrs. The cells were seeded on well chamber and treated with SOF $1 \mu \mathrm{M}$ for $24 \mathrm{hrs}$ to determine the effects of the genes in migration activity. The migratory distance of the cells was quantified with ImageJ software and expressed as the mean \pm SEM from three independent experiments. ( $\left.{ }^{*} p<0.05 ; * \star p<0.01 ; \quad * \star * p<0.001\right)$.

\section{Supplementary Files}

This is a list of supplementary files associated with this preprint. Click to download.

- supplemetalmaterial.docx 